\title{
Short-term responses in production and behavior during periods of change in concentrate allowance for dairy cows
}

\author{
J. C. S. Henriksen, ${ }^{1}$ L. Munksgaard, and M. R. Weisbjerg \\ Department of Animal Science, Aarhus University, Blichers allé 20, 8830 Tjele, Denmark
}

\begin{abstract}
The aim of this study was to investigate the shortterm responses of dairy cows during periods of change in the concentrate allowance in an automatic milking system. The experiment had a design with a $2 \times 2$ factorial arrangement including 2 types of concentrates and 2 amounts of concentrates (type O: mix of pelleted concentrate and steamrolled, acidified barley; type $\mathrm{S}$ : pelleted) in amounts of 3 and $6 \mathrm{~kg} / \mathrm{d}$. The experiment length was $11 \mathrm{wk}$. The concentrate type changed between wk 6 and 7 and included both increase and decrease in concentrate allowance for each concentrate type. The concentrate allowance was changed by 0.5 $\mathrm{kg} / \mathrm{d}$ over 6 d. The 96 cows (48 Danish Jersey, 48 Danish Holstein) included in the experiment were blocked according to breed, parity, and days in milk, and randomly divided into 8 groups of treatment order. The cows visited the automatic milking unit more often when concentrate type $\mathrm{O}$ was offered, but not when an increased concentrate allowance was provided. The changes in concentrate intake and partial mixed ration (PMR) eating time showed a symmetrical pattern between the periods of increasing allowance and decreasing allowance. However, PMR intake and milk yield varied in the magnitude of the responses, indicating that these responses may not be driven by the same underlying mechanisms during increase and decrease in concentrate allowance. The daily lying time increased and the PMR eating rate decreased during periods of both increase and decrease in concentrate allowance. We found no significant change in milk yield during increase in concentrate allowance, despite a higher milk yield during periods with constant concentrate allowance at the high concentrate amount; however, the milk yield decreased during periods of decrease in concentrate allowance. Visit frequency, lying time,
\end{abstract}

Received February 22, 2018.

Accepted May 1, 2018.

${ }^{1}$ Corresponding author: juliec.henriksen@anis.au.dk and steps changed during periods of changes in concentrate allowance without showing any differences at the constant concentrate allowance. In conclusion, these results indicate that it may be difficult to adjust the individual concentrate allowance based on the shortterm responses of the cow.

Key words: dairy cow, concentrate change, production, behavior

\section{INTRODUCTION}

Since the beginning of the last century, dairy cows in Europe have been fed according to their individual milk production by adjusting the amount of concentrate in the individual ration (Østergaard et al., 1987). However, the herd size has increased (Kristensen et al., 2015) and housing has changed to loose housing instead of tiestall barns. These changes led to an increase in the use of group feeding (Østergaard et al., 1987; Schingoethe, 2017), which is a simple way to manage the feeding of a large herd; however, group feeding does not account for individual variation in nutritional requirements. Recently, the amount of automated individual data has increased due to implementation of systems such as the automatic milking unit (AMU; Bach and Cabrera, 2017), making it possible to adjust the individual concentrate allowance based on individual responses, and also for large herds.

The increased interest in and use of individual concentrate strategies emphasizes the need to understand how dairy cows respond to adjustments in concentrate allowance. Most previous researchers studied how cows respond to concentrate changes after an adaption period. However, to use the immediate responses to changes in concentrate allowance for further adjustment, there is a need for more research regarding the adaptation to change in concentrate allowance.

Based on existing knowledge concerning the effects of concentrate offered during periods of constant concentrate allowance, our hypotheses was that an increase in concentrate allowance would have the potential to increase milking frequency and milk yield (Halachmi et al., 2005; Weisbjerg and Munksgaard, 2008; Lawrence 
et al., 2015) but decrease the ad libitum partial mixed ration (PMR) intake (Weisbjerg and Munksgaard, 2008). To the best of our knowledge, only Bach et al. (2007) included feeding behavior in a study comparing the effects of concentrate allowance, and those authors showed that a high concentrate allowance resulted in a slower PMR eating rate without affecting the daily PMR eating time. Therefore, we expected a decrease in PMR intake might be followed by a decrease in PMR eating time or a change in the eating rate, thus allowing more time for lying down. Additionally, as a previous study has shown that a more preferred type of concentrate can increase milking frequency (Madsen et al., 2010), our hypothesis was that a more preferred concentrate type may result in similar effects on the responses of the cow as increased concentrate allowance. At last, because cows are adapting to changes in the ration during periods of adjustments in concentrate allowance, we expected that the responses of the cows would show greater variation during periods of changes in concentrate allowance than during periods of constant concentrate allowance. Therefore, the aim of our study was to investigate the short-term responses in production and behavior of dairy cows in an automatic milking system during periods of increased and decreased concentrate allowance, including 2 concentrate types expected to differ in preference.

\section{MATERIALS AND METHODS}

\section{Experimental Facilities and Animals}

The experiment was conducted at the Danish Cattle Research Center using an automatic milking system (DeLaval AB, Tumba, Sweden) with free cow traffic. The barn had a slatted floor covered with rubber in the waiting area in front of the AMU and cubicles with mattresses; a mixture of cut rapeseed straw and sawdust was used as bedding. The experiment included
48 Danish Holstein (DH) cows in a group of 58 cows, on average $($ minimum $=54 ;$ maximum $=64)$, and 48 Danish Jersey (DJ) cows in a group of 59 cows, on average $($ minimum $=56$; maximum $=61)$. Each group had access to 1 AMU. The AMU system recorded the amount of concentrate allocated to each cow and was equipped with a device for weighing individual concentrate leftovers. The maximum output of concentrate was set according to the treatment, and the allowance was divided on an hourly basis and allocated at each visit. The concentrate was allocated at a rate of $500 \mathrm{~g} /$ min, allowing a maximum of $50 \%$ of the daily allowance per visit. The AMU could save up to $50 \%$ of the daily allowance for the next day. The concentrate feeder in the AMU was calibrated every second week. Each AMU had a weighing platform to record the BW of the cow at each milking (Danvaegt, Hinnerup, Denmark). The cows had free access to water and were fed the PMR for ad libitum intake in feed bins for automatic recording of individual feed intake (RIC; Insentec Roughage Intake Control system, Insentec BV, Marknesse, the Netherlands). The PMR fed in these feed bins had a concentrate-to-forage ratio of 35:65. All feed bins in each section were available to all cows, with 28 feed bins in the DH section and 25 feed bins in the DJ section. The PMR was mixed once a day in a mixer wagon, and the feed bins were refilled with the PMR 4 times/d and emptied for leftovers 3 times/wk.

\section{Experimental Design}

The experiment had a crossover design with a $2 \times 2$ factorial arrangement, including 2 types of concentrates and 2 amounts of concentrates (3 vs. $6 \mathrm{~kg}$; Table 1). The experiment was carried out over a period of 11 wk, including a shift in concentrate type after wk 6 . Concentrate type $\mathrm{S}$ was a pelleted concentrate, and concentrate type $\mathrm{O}$ was a mix of pelleted concentrate and steamrolled, acidified barley. In a previous study,

Table 1. The 8 orders of treatments, including 2 levels of concentrate amount ${ }^{1}$ and 2 concentrate types $^{2}$ during constant concentrate allowance, increase in allowance, and decrease in allowance ${ }^{3}$

\begin{tabular}{|c|c|c|c|c|c|c|c|c|c|c|c|}
\hline Week & 1 & 2 & 3 & 4 & 5 & 6 & 7 & 8 & 9 & 10 & 11 \\
\hline 2 & S3 & S3 & $\mathrm{S} \uparrow 6$ & S6 & $\mathrm{S} \downarrow 3$ & S3 & $\mathrm{O} \uparrow 6$ & O6 & $\mathrm{O} \downarrow 3$ & O3 & $\mathrm{O} \uparrow 6$ \\
\hline 3 & $\mathrm{~S} \uparrow 6$ & S6 & $\mathrm{S} \downarrow 3$ & S3 & $\mathrm{S} \uparrow 6$ & S6 & $\mathrm{O} \downarrow 3$ & O3 & $\mathrm{O} \uparrow 6$ & O6 & $\mathrm{O} \downarrow 3$ \\
\hline 5 & $\mathrm{O} 3$ & O3 & $\mathrm{O} \uparrow 6$ & O6 & $\mathrm{O} \downarrow 3$ & O3 & S3 & S3 & $\mathrm{S} \uparrow 6$ & S6 & $\mathrm{S} \downarrow 3$ \\
\hline 6 & O3 & O3 & $\mathrm{O} \uparrow 6$ & O6 & $\mathrm{O} \downarrow 3$ & O3 & $\mathrm{S} \uparrow 6$ & S6 & $\mathrm{S} \downarrow 3$ & S3 & $\mathrm{S} \uparrow 6$ \\
\hline 7 & $\mathrm{O} \uparrow 6$ & $\mathrm{O} 6$ & $\mathrm{O} \downarrow 3$ & O3 & $\mathrm{O} \uparrow 6$ & O6 & $\mathrm{S} \downarrow 3$ & S3 & $\mathrm{S} \uparrow 6$ & S6 & $\mathrm{S} \downarrow 3$ \\
\hline
\end{tabular}

${ }^{1} 3=3 \mathrm{~kg} / \mathrm{d} ; 6=6 \mathrm{~kg} / \mathrm{d}$.

${ }^{2} \mathrm{~S}=$ concentrate type $\mathrm{S}$ (pelleted concentrate); $\mathrm{O}=$ concentrate type $\mathrm{O}$ (mix of pelleted concentrate and steamrolled, acidified barley).

$3 \uparrow=$ increase in concentrate allowance; $\downarrow=$ decrease in concentrate allowance. 
Table 2. The number of cows in the experiment, including DIM, ECM yield, BW, BCS, ${ }^{1}$ and lameness score $\left(\mathrm{LS}^{2} ;\right.$ mean $[$ minimum; maximum])

\begin{tabular}{lccccc}
\hline Item $^{3}$ & Cows & ECM yield, ${ }^{4} \mathrm{~kg} / \mathrm{d}$ & DIM $^{4}$ & BW, ${ }^{4} \mathrm{~kg}$ & BCS $^{1,5}$ \\
\hline DH, 1 & 22 & $36[19 ; 60]$ & $128[23 ; 320]$ & $615[482 ; 729]$ & $3.2[3.00 ; 3.50]$ \\
DH, $>1$ & 19 & $47[23 ; 70]$ & $128[14 ; 330]$ & $724[613 ; 814]$ & $3.2[2.75 ; 3.75]$ \\
DJ, 1 & 14 & $24[14 ; 33]$ & $102[29 ; 218]$ & $441[367 ; 506]$ & $3.2[3.00 ; 3.50]$ \\
DJ, $>1$ & 28 & $30[10 ; 43]$ & $106[17 ; 267]$ & $520[429 ; 612]$ & $3.2[3.00 ; 3.50]$ \\
\hline
\end{tabular}

${ }^{1}$ BCS determined as described by Ferguson et al. (1994).

${ }^{2}$ LS determined as described Thomsen et al. (2008).

${ }^{3}$ Breed: Danish Holstein $=$ DH; Danish Jersey $=$ DJ. Parity: primiparous $=1$; multiparous $>1$.

${ }^{4} \mathrm{LSM}$ as an average of the first $3 \mathrm{~d}$ in the experimental period including cows entering in wk 6 .

${ }^{5} \mathrm{BCS}$ and LS are based on recordings from a single day.

cows showed a higher preference for concentrate type O compared with concentrate type S (Primdal et al., 2014), and concentrate type $\mathrm{S}$ was fed to the cows before the initiation of the experiment.

The experiment started with 1 wk of adaptation to the concentrate amount and type. Half of the cows were fed type $\mathrm{S}$ and the other half were fed type $\mathrm{O}$; within each group, half of the cows started in first period of the experiment (wk 1 to 6 ) with $6 \mathrm{~kg}$ of concentrate and the other half started with $3 \mathrm{~kg}$ of concentrate (Table 1). Weeks 1,6 , and 7 were adaption periods, as new cows were entering the experiment during wk 6 to be included in the second half of the experiment (wk 7 to 11). The amount of concentrate was increased or decreased over a 6 -d period at a rate of $0.5 \mathrm{~kg} / \mathrm{d}$. In each group, each cow was subjected to both an increase and decrease in concentrate allowance. The cows were blocked according to breed (DH or DJ), parity (primiparous or multiparous), and DIM, and then randomly distributed within block between the 8 orders of treatments (Table 1 ).

Animals. A total of 96 cows (48 DH and 48 DJ) were included in the experiment. However, data from 13 cows $(\mathrm{DH}=7, \mathrm{DJ}=6)$ were excluded from analyses due to disease incidents registered by a veterinarian (e.g., mastitis, ketosis, and follicular cystic ovary disease). The exclusion criteria were defined as disease resulting in a decrease in milk yield and feed intake during more than 2 wk of the experimental period or more than 2 disease incidents during the experimental period. Twenty other cows were excluded for 1 or 2 wk if the cow was in heat according to an increase in activity (head and neck movements) or due to shorter disease periods. The total of 83 different cows for both periods of the experiment used for further analyses were distributed according to breed, parity, and DIM across both experimental periods, as shown in Table 2; cows were at least $14 \mathrm{~d}$ from calving when the experiment started and at least $70 \mathrm{~d}$ from expected calving when the experiment finished. The start date for the first period (wk 1 to 6 ) of the experiment was August 5, 2014, where 68 cows $(\mathrm{DH}=$
32 , DJ $=36$ ) were included. The second period (wk 7 to 11) began on September 16, 2014, where 15 new cows $(\mathrm{DH}=8, \mathrm{DJ}=7)$ were included in the experiment and 8 cows from period $1(\mathrm{DH}=3, \mathrm{DJ}=5)$ were excluded ( 75 cows total; $\mathrm{DH}=37, \mathrm{DJ}=38$ ).

The daily milk yield, DIM, BW, BCS, and lameness score (LS) were calculated based on d 1 to 3 during wk 1 of the experimental period and based on d 1 to 3 during wk 7 for the 15 cows entering the study in the second half of the experiment. The results are presented in Table 2.

Feed Composition. The forage consisted of a mixture of grass, clover, and corn silage. The concentrate contained spring barley, wheat, rapeseed cake, soybean meal, dried sugar beet pulp, and minerals (Table 3). The ration was formulated using the Nordic Feed Evaluation System model and standards (Volden, 2011).

\section{Data Recording}

$\boldsymbol{P M R}$ Intake. The daily frequency and duration of visits to the feed bins were recorded together with the intake of PMR in kilograms of feed. A visit to the feed bin was recorded by the RIC bins via transponders placed on the ear of each cow. The individual PMR intake was calculated according to previously described methods (Bossen et al., 2009). The duration of each visit to the feed bin was summarized per day to give the daily duration of eating $(\mathrm{min} / \mathrm{d})$. The PMR eating rate was calculated as the intake of PMR in grams of DM per day divided by the daily time spent on eating (g of DM/min eating).

Samples of the silages and concentrates were collected every week and pooled for each subperiod of the experiment (wk 1 to 6 and wk 7 to 11). The DM content was determined by drying in a forced-air oven at $60^{\circ} \mathrm{C}$ for $48 \mathrm{~h}$. Samples were milled through a $1-\mathrm{mm}$ screen before chemical analysis (ZM 200 Mill, Retsch GmbH, Haan, Germany). Ash was analyzed by weighing after combustion at $525^{\circ} \mathrm{C}$ (AOAC International, 2000). Crude fat was analyzed by Soxhlet extraction 
with petroleum ether after hydrolyzing with $\mathrm{HCl}$ using a Soxtec system (Foss Analytical, Hillerød, Denmark). Crude protein was calculated based on analysis of total $\mathrm{N}$ according to the Dumas principle (Hansen, 1989) using a Vario MAX CN (Elementar Analysesysteme GmbH, Hanau, Germany). Starch was analyzed by an enzymatic colorimetric technique (Knudsen et al., 1987). Sugar was analyzed by the Luff-Schoorl method (European Community, 2012; 71/250/EEC). The NDF content was analyzed using a Fibertec M6 (Foss Analytical) system with amylase and sulfite treatment and corrected for ash content (Mertens et al., 2002). In vitro digestibility of $\mathrm{OM}$ of concentrates was determined by treating the samples with pepsin- $\mathrm{HCl}$ solution, followed by incubation with fiber-degrading enzymes (Weisbjerg and Hvelplund, 1993).

Milk Yield and Composition. The milk yield was recorded at every milking at the AMU. For further analysis of the milk composition (fat, $\mathrm{CP}$, and lactose monohydrate), representative milk samples were collected for all milking episodes for a full week during the periods of increase and decrease in concentrate allowance $(7 \mathrm{~d}$ in a row), and for $2 \mathrm{~d}$ in a row every second week (the last $2 \mathrm{~d}$ of periods with constant concentrate allowance) by a modified milk sampler system (XMS,
DeLaval; Løvendahl and Bjerring, 2006; Larsen et al., 2012). The milk samples were preserved with bronopol and kept at $2^{\circ} \mathrm{C}$ until the samples were analyzed at Eurofins (Holstebro, Denmark).

Visits to the AMU. The AMU system recorded the daily frequency of complete milkings, incomplete milkings, and rejected milking attempts. The cows were allowed access to the AMU when the expected milk yield reached $6 \mathrm{~kg}$ for DJ cows and $7 \mathrm{~kg}$ for DH cows, or when the time from the last milking was at least 11 h. Cows were fetched for milking at the AMU if the interval from the last milking exceeded $15 \mathrm{~h}$ and if the visit frequency to the AMU for the past $4 \mathrm{~d}$ had been below $1.55 / \mathrm{d}$, on average. Involuntary milkings (proportion of cows fetched for milking) were calculated as the proportion of involuntary milkings of all milkings for each period of concentrate allowance (constant, increase, and decrease in concentrate allowance).

Activity. An activity pedometer (AfiTagII, AfiMilk, Kibbutz Afikim, Israel) was attached to 1 hind leg of each cow to record the daily lying time, frequency of lying bouts, and steps. All cows were equipped with electronic activity tags (Alpro, version 6.60, DeLaval, 2007) placed on the neckband; these data were used for heat detection.

Table 3. Ingredient composition of the partial mixed ration (PMR) and the 2 concentrate types, and measured nutrient composition

\begin{tabular}{lccc}
\hline Item & PMR & Concentrate S & Concentrate O \\
\hline Ingredient, \% of DM & 32.1 & 0 & 0 \\
Corn silage & 31.9 & 0 & 0 \\
Grass-clover silage & 3.6 & 12.6 & $17.6^{1}$ \\
Spring barley & 0 & 14.5 & 8.8 \\
Rapeseed meal & 11.3 & 0 & 0 \\
Rapeseed cake & 8.8 & 12.6 & 2.8 \\
Wheat & 0 & 4.3 & 12.3 \\
Wheat bran & 4.1 & 7.7 & 0 \\
Soybean meal & 0 & 6.0 & 17.6 \\
Sunflower meal & 5.5 & 145 & 3.5 \\
Beet pulp & 0 & 4.3 & 5.6 \\
Alfalfa, artificially dried & 0 & 0 & 2.6 \\
Corn & 0 & 6.0 & 2.6 \\
Citrus pulp & 0 & 2.6 & 0 \\
Molasses & 0.2 & 0.6 & 0.2 \\
NaCl & 0.8 & 0.3 & 0 \\
Mineral and vitamin mix & 0 & 0.1 & 1.1 \\
Magnesium oxide & 0 & 0 & 88.5 \\
Palm fatty acid distillates & & & 6.3 \\
Chemical composition & 58.1 & 86.6 & 6.0 \\
DM, \% & 6.4 & 7.9 & 25.8 \\
Crude ash, \% of DM & 4.1 & 4.2 & 24.0 \\
Crude fat, \% of DM & 15.9 & 24.0 & 10.4 \\
CP, \% of DM & 16.1 & 25.9 & 25.1 \\
Starch, \% of DM & 5.3 & 11.3 & 91.3 \\
Sugar, \% of DM & 31.5 & 25.2 & \\
NDF, \% of DM & - & 91.2 & \\
EFOS, \% of OM & & & \\
\hline Steanroll, aidifed & & & \\
\hline
\end{tabular}

${ }^{1}$ Steamrolled, acidified barley.

${ }^{2} \mathrm{EFOS}=$ in vitro organic matter digestibility (Weisbjerg and Hvelplund, 1993). 
$\boldsymbol{B} \boldsymbol{W}, \boldsymbol{B C S}$, and $\boldsymbol{L S}$. Body weight was recorded at every visit to the AMU by a weight platform. The daily BW was calculated as an average of BW per visit on the same date, and weight data were cleaned as described by Bossen et al. (2009). The BCS and LS were performed on Tuesday every second week by 1 of 2 trained personnel. The BCS was based on a 1 to 5 scale with intervals of 0.25 , where 1 represents very lean cows and 5 represents very fat cows (Ferguson et al., 1994). The LS was based on a 1 to 5 scale, with 1 being normal walking without any sign of lameness and 5 being strongly lame with more than 1 leg being affected (Thomsen et al., 2008). All treatments of disease incidents were recorded.

\section{Data and Statistical Analyses}

Data Processing. Outlier detection for intake of PMR was conducted as described by Bossen et al. (2009). The daily milk yield was based on a 24-h calculation from midnight to midnight, assuming that the milk yield at a given milking was produced at a constant rate since the last milking. The milk yield recorded at the first and last milking episodes of a 24-h period were divided proportionally to the time from midnight and allocated to the days. For further details of recording and validation of the milk data, see Bossen and Weisbjerg (2009). Calculation of ECM was performed by including the assumption that a standard energy content of milk equals $3.14 \mathrm{MJ} / \mathrm{kg}$ (Sjaunja et al., 1991). The results of both the fetched cows and cows entering the AMU voluntarily were included in the analyses.

Outlier detection and calculations of daily lying time of the AfiTagII data were conducted as described by Henriksen and Munksgaard (2016), and the criterion for inclusion of data was that measured intervals for a 24-h period summed up to 1410 to $1470 \mathrm{~min}$.

Statistics. Analyzes were performed separately on data from the periods of constant concentrate allowance and the periods of increase and decrease in concentrate allowance. The statistical analyses were performed using the MIXED procedure using SAS 9.3 (Littell et al., 2006), and the given estimates are presented as the least squares means and standard error of the mean. The degrees of freedom were estimated by the Satterthwaite method. The daily frequency of visits to the AMU, lying bouts, steps, and PMR eating rate were log-transformed to obtain a normal distribution of data. Contrast analyses of the interactions were performed. Effects with $P<0.05$ were characterized as significant.
Statistical Models. Model 1 was used to analyze data from the periods of constant concentrate allowance. The fixed effects were concentrate type $(T)$ at $j$ levels, $j=1,2$; concentrate amount $(A)$ at $k$ levels, $k$ $=1,2$; parity $(P)$ at $i$ levels, $i=1,2(2=$ parity $>1)$; breed $(B)$ at $h$ levels, $h=1,2$; DIM $(d)$ was included as a covariate $(\beta)$. The day within the cow and week was regarded as repeated, $m=1,2,3,4,5,6,7$. The cow number was denoted as $l$. Model 1 was written as

$$
\begin{gathered}
Y_{h i j k l m}=\mu+T_{j}+A_{k}+B_{h}+P_{i}+T \times A_{j k} \\
+T \times B_{h j}+A \times B_{h k}+T \times P_{i j}+A \times P_{i k} \\
+B \times P_{h i}+T \times A \times B_{h j k}+T \times A \times B \times P_{h j k i} \\
+\beta \times d_{l}+Z_{l m(j k)}+\varepsilon_{h i j k l m},
\end{gathered}
$$

where $Y_{\text {hijklm }}=$ response variable, $\mu=$ mean of response variable, $Z_{l m(k j)}=$ the random effects of the cow, $\varepsilon_{h i j k l m}=$ the random residual error; $\varepsilon_{h i j k l m} \sim N\left(0, \sigma^{2}\right)$.

The covariance structure used was defined as compound symmetry or variance components if this variance structure gave a lower Akaike information criterion value. The model for each response was reduced by omitting nonsignificant interactions between 3 and 4 fixed effects.

Model 2 was used for data from the periods of increase and decrease in concentrate allowance. A linear regression on the weekday $(m)$, with $\alpha$ as the regression coefficient, was included. Model 2 was written as

$$
\begin{aligned}
& Y_{h i j l m}=\mu+T_{j}+B_{h}+P_{i}+T \times B_{h j}+T \times P_{i j} \\
&+\alpha \times m+\alpha \times m \times T_{j}+\alpha \times m \times B_{h}+\alpha \times m \\
& \times P_{i}+\beta \times d_{l}+Z_{l m(j)}+\varepsilon_{h i j l m},
\end{aligned}
$$

where $Y_{\text {hijlm }}=$ response variable, $\mu=$ mean of response variable, $Z_{l m(j)}=$ the random effects of the cow, $\varepsilon_{h i j l m}=$ the random residual error; $\varepsilon_{h i j m} \sim N\left(0, \sigma^{2}\right)$.

The covariance structure used was defined as compound symmetry or variance components if this variance structure gave a lower Akaike information criterion value. The model for each response was reduced by omitting nonsignificant interactions between fixed effects, except for the interaction between the weekday and concentrate type.

The standard deviation of the responses in the periods of increase and decrease in concentrate allowance was tested by model 3 for the effect of the weekday. The weekday $(W)$ was included as a fixed effect at the $m$ level, $m=1,2,3,4,5,6,7$. The week was included as a random effect at the $k$ level, $k=1,2,3,4$ (wk 3, 5, 9 and 11). Model 3 was written as 


$$
\begin{gathered}
Y_{h i j k m}=\mu+T_{j}+B_{h}+P_{i}+W_{m}+W \times T_{m j} \\
+W \times B_{m h}+W \times P_{m i}+B \times P_{h i}+B \times T_{h j} \\
+P \times T_{i j}+Z_{k(j)}+\varepsilon_{h i j k m},
\end{gathered}
$$

where $Y_{h i j k m}=$ response variable, $\mu=$ mean of response variable, $Z_{k(j)}=$ the random effects of the week, and $\varepsilon_{h i j k m}=$ the random residual error, $\varepsilon_{h i j k m} \sim N\left(0, \sigma^{2}\right)$.

To validate if the amount of work related to fetched cows may differ between periods of constant concentrate allowance or increased and decreased concentrate allowance, the proportion of involuntary milking episodes of all milking episodes of different concentrate allowances was compared using the PROC ANOVA procedure in SAS. The concentrate allowance period (constant, increased, and decreased concentrate allowance) and concentrate type were fixed effects.

\section{RESULTS}

\section{Constant Concentrate Allowance}

The results based on data from the periods of constant concentrate allowance are presented in Table 4 . We found no significant interactions between the concentrate amount and the concentrate type, and only the PMR eating rate differed between parities. Milk yield and lactose content increased and fat and protein content decreased with increasing DIM. These results are not presented in the tables.

Feed Intake. The mean concentrate intake differed between the 2 levels of concentrate allowance (Table 4). For both breeds, the cows that were offered $3 \mathrm{~kg} / \mathrm{d}$ $(2.6 \mathrm{~kg}$ of $\mathrm{DM} / \mathrm{d})$ ate $2.5 \pm 0.5 \mathrm{~kg}$ of $\mathrm{DM} / \mathrm{d}$, and the cows offered $6 \mathrm{~kg} / \mathrm{d}(5.3 \mathrm{~kg}$ of DM/d) ate $3.8 \pm 1.2 \mathrm{~kg}$ of DM/d (data not shown in table). Both the type and amount of concentrate affected the intake. The cows ate more concentrate at a concentrate allowance of $6 \mathrm{~kg} / \mathrm{d}$, compared with $3 \mathrm{~kg} / \mathrm{d}$, and when offered concentrate type $\mathrm{O}$ versus type $\mathrm{S}$. The DJ cows had a higher concentrate intake than the $\mathrm{DH}$ cows for both concentrate types and at the concentrate allowance of $6 \mathrm{~kg} / \mathrm{d}$. The daily PMR intake was lower at a concentrate allowance of $6 \mathrm{~kg} / \mathrm{d}$ compared with $3 \mathrm{~kg} / \mathrm{d}$, but the PMR intake did not depend on the concentrate type. The DH cows had a higher PMR intake than the DJ cows.

Milk Yield and Composition. The daily concentrate allowance of $6 \mathrm{~kg} / \mathrm{d}$ resulted in the highest milk production both for the daily milk yield and ECM yield, and the milk yield was higher when the cows were offered concentrate type $\mathrm{O}$ compared with type S. Compared with the DJ cows, the DH cows had a greater daily milk yield and ECM yield.
Both the milk fat and milk protein content were the highest when the cows where offered concentrate type $\mathrm{S}$ for multiparous DJ cows. The fat content in the milk was highest for the DJ cows when the concentrate allowance was $3 \mathrm{~kg} / \mathrm{d}(6.01 \%, \mathrm{SEM}=0.12 ; P<0.001)$, and the protein content in the milk was highest for the DJ cows when the concentrate allowance was $6 \mathrm{~kg} / \mathrm{d}$ (4.69\%, SEM $=0.07 ; P=0.043$; data not shown in table).

Behavior. The daily visit frequency and milkings at the AMU did not differ between the 2 concentrate levels. The daily milkings were higher when the cows were fed concentrate type O compared with type S. The DJ cows had a higher daily visit frequency than the DH cows, but the daily milkings did not differ between the 2 breeds. In addition, the proportion of involuntary milkings did not differ significantly between the different types of concentrate allowance (constant $=2.6 \pm$ $0.7 \%$, increase $=2.2 \pm 0.02 \%$, decrease $=2.6 \pm 0.4 \%$; $P=0.59)$, or between the 2 concentrate types $(\mathrm{S}=2.8$ $\pm 0.09 \% ; \mathrm{O}=2.2 \pm 0.5 \% ; P=0.21$.

Cows at the daily concentrate allowance of $3 \mathrm{~kg} / \mathrm{d}$ spent longer time eating the PMR than cows at the 6 $\mathrm{kg} / \mathrm{d}$ allowance. The DH cows spent longer time on eating the PMR when the cows were offered concentrate type O compared with type S (200 vs. $194 \mathrm{~min} / \mathrm{d} ; P$ $=0.05)$, and the opposite effect was observed for the DJ cows (155 vs. $161 \mathrm{~min} / \mathrm{d}, P=0.03$; data not shown in table). The eating rate of the PMR did not differ significantly between treatments, but primiparous cows had a slower eating rate than multiparous cows.

The lying time did not differ between the 2 levels of concentrate allowance, but the lying time was shorter for the $\mathrm{DH}$ cows when concentrate type $\mathrm{O}$ was offered compared with type S. The DJ cows had a shorter lying time than DH cows. The cows tended to have a higher frequency of lying bouts at the daily concentrate allowance of $6 \mathrm{~kg} / \mathrm{d}$. In addition, DJ cows tended to have a higher daily frequency of lying bouts when concentrate type $\mathrm{O}$ was offered compared with type $\mathrm{S}$; the opposite was true for the DH cows. The daily number of steps was higher for DJ cows compared with DH cows, but we found no significant difference in the number of steps for the various treatments.

\section{Changes in Concentrate Allowance}

The results based on data from the periods of increase and decrease in concentrate allowance are presented in Table 5. The effects of breed and parity were not significant and therefore not presented. The interactions between the change in weekday and parity, as well as the interaction between the change in weekday and 
HENRIKSEN ET AL.

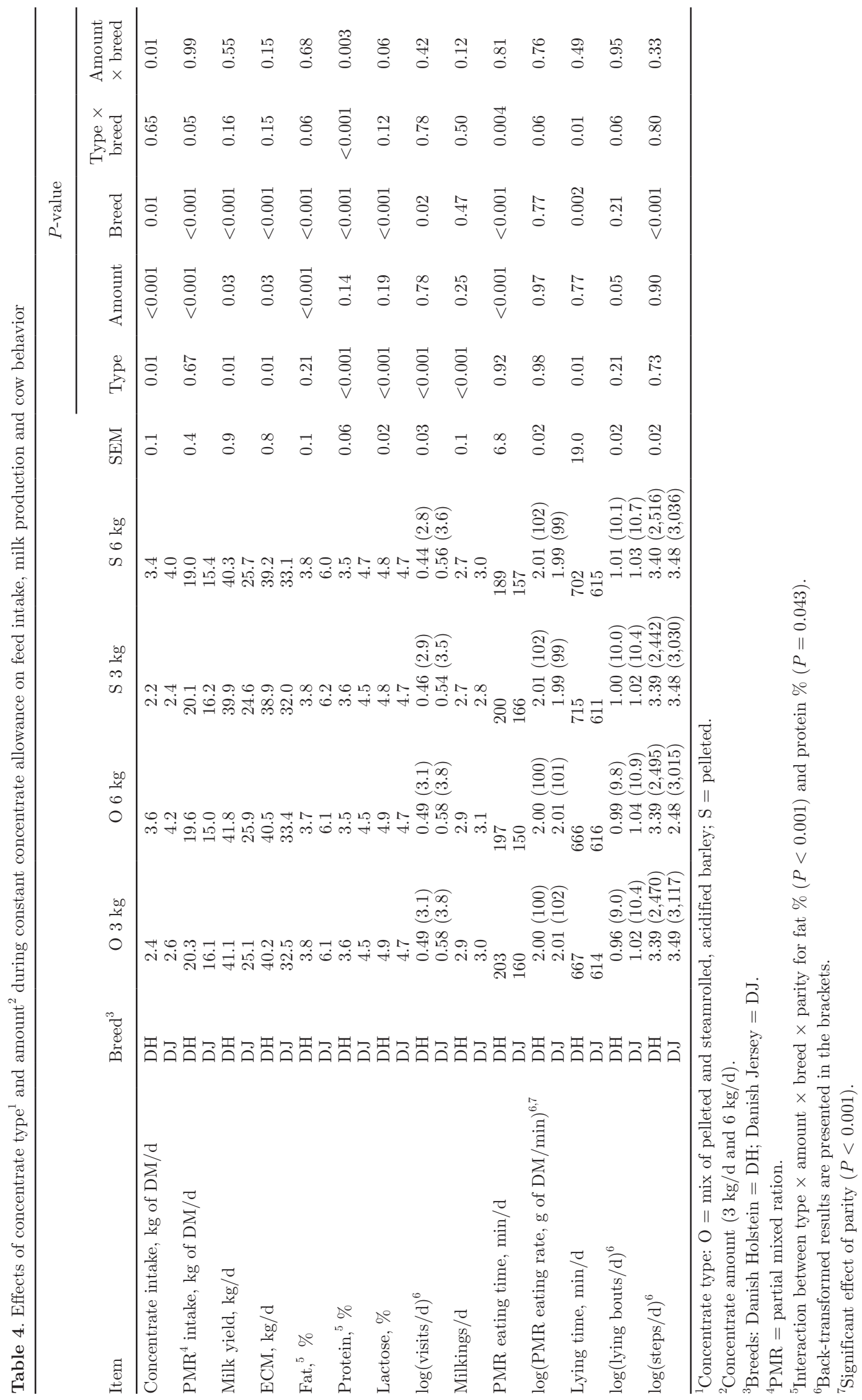


breed, are not presented, as most of these results were not significant.

Increase in Concentrate Allowance. During the periods of increase in concentrate allowance from 3 to $6 \mathrm{~kg} / \mathrm{d}$, the daily concentrate intake increased; intake increased even more when the cows were fed concentrate type $\mathrm{O}$. The daily intake of PMR decreased as concentrate increased. The slope for milk yield and the ECM yield did not differ significantly from zero with the increase in concentrate, and neither did the slope for the fat and lactose content in the milk. The protein content in the milk increased as concentrate increased; the slope for daily milkings did not differ significantly from zero and the frequency of visits to the AMU decreased. The daily PMR eating time and the PMR eating rate decreased as concentrate increased, with primiparous cows having the slowest eating rate. The daily lying time increased with concentrate increase, but the slope of the daily frequency of lying bouts and steps did not differ significantly from zero.

Decrease in Concentrate Allowance. During the periods of decrease in concentrate allowance from 6 to $3 \mathrm{~kg} / \mathrm{d}$, the daily concentrate intake decreased and the daily PMR intake increased. The daily milk yield decreased, and the slopes of the ECM yield and protein content in the milk did not differ significantly from zero with the decrease in concentrate. In addition, the fat and lactose content in the milk increased, and when the cows were offered concentrate type $\mathrm{S}$ the fat content in the milk tended to have a higher increase compared with type $\mathrm{O}$. The slopes of the daily milkings and visit frequency to the AMU did not differ significantly from zero with the decrease in concentrate allowance, whereas the daily PMR eating time increased and the PMR eating rate decreased. The daily lying time increased, but the slope of the daily frequency of lying bouts did not differ significantly from zero as concentrate decreased; moreover, the daily number of steps decreased.

The standard deviation of intake increased during both periods of increased and decreased concentrate allowance compared with the periods of constant concentrate allowance $(P<0.001)$. No other responses increased the standard deviation during periods of concentrate changes in the AMU, and the concentrate type did not affect the standard deviation. These results were analyzed using model 3 .

\section{DISCUSSION}

The changes in concentrate intake, PMR eating time, and lying bouts showed a symmetrical pattern between the periods of increase and decrease in concentrate allowance. However, for the PMR intake, the magnitude of the changes varied between the periods of increase 
and decrease in concentrate allowance, indicating that this response may not be driven by the same underlying mechanisms during periods of increased and decreased concentrate allowance. We found no significant change in the milk yield during periods of increase in concentrate allowance, despite a higher milk yield during periods with constant concentrate allowance at the highest level of concentrate. However, the milk yield decreased by $0.05 \mathrm{~kg} / \mathrm{d}$ during periods of decrease in concentrate allowance.

\section{Concentrate Intake}

The daily concentrate intake increased during periods of increased concentrate allowance and decreased during periods of decreased concentrate allowance; however, in agreement with previous studies, the cows did not eat all of the offered concentrate, especially at the high concentrate allowance. In previous studies that fed cows with a high level of concentrate combined with a high-energy PMR, an intake between 66 and $88 \%$ of the concentrate allowance at the high concentrate level (6 to $7 \mathrm{~kg} / \mathrm{d}$ ) was reported (Bach et al., 2007; Weisbjerg and Munksgaard, 2008; Bossen and Weisbjerg, 2009). Thus, the concentrate intake in terms of the percentage of the allowance in our study was at the low end compared with previous findings. The DH and DJ cows differed in concentrate intake at the high concentrate allowance, with DJ cows eating $69 \%$ of the daily allowance and DH cows eating $59 \%$ of the daily allowance. A possible explanation for the lower intake of the allowance in our study is the high allocation rate of the concentrate in the AMU, which might have resulted in more leftover concentrate. The allocation rate in our study was $200 \mathrm{~g} / \mathrm{min}$ higher than that reported in other studies (Halachmi et al., 2005; Bossen et al., 2009). The cows in our study ate more concentrate type $\mathrm{O}$ than type $\mathrm{S}$, indicating that concentrate type $\mathrm{O}$ was the preferred type, which is in agreement with an earlier preference test (Primdal et al., 2014). Besides palatability, the positive effect of concentrate type $\mathrm{O}$ on the motivation to enter the AMU could also be explained by a novelty effect. The cows were familiar with concentrate type $\mathrm{S}$ for a longer period before the experiment, whereas they were only offered concentrate type $\mathrm{O}$ during the experiment. The larger variation in concentrate intake during periods of concentrate changes compared with the periods with constant concentrate allowance may reflect differences in individual responses to the changes in concentrate allowance. Of note, a high individual variation in the motivation to perform feed-related exploratory behavior and the fear of novelty have been demonstrated in calves and heifers (Atwood et al., 2001; Meagher et al., 2017).

\section{PMR Intake}

The larger response of the PMR intake during periods of increase as opposed to during periods of decrease in concentrate allowance might reflect a delayed effect to the decreasing allowance of concentrate in the AMU. As the mean intake of concentrate for both DH and DJ cows was $3.8 \mathrm{~kg} / \mathrm{d}$ at the high concentrate allowance, the effect of the $0.5 \mathrm{~kg} / \mathrm{d}$ reduction on the feed intake during periods of decrease in concentrate allowance will appear after some days. The cows ate approximately $1 \mathrm{~kg}$ of $\mathrm{DM} / \mathrm{d}$ less of the PMR when the concentrate allowance increased from 3 to $6 \mathrm{~kg} / \mathrm{d}$ during the periods of constant concentrate allowance. This change in PMR intake is comparable to some previous findings (Dewhurst et al., 2002; Bach et al., 2007), whereas other studies did not see an effect on the PMR intake (Weisbjerg and Munksgaard, 2008; Lawrence et al., 2015). The results of our study reflect the high energy density of the PMR (Jensen et al., 2016), as the effect of concentrate substitution on the PMR intake depended on the energy density of the PMR ration, with an increasing substitution with an increasing energy density of the PMR. The higher intake of concentrate type $\mathrm{O}$ compared with type S did not affect the PMR intake, indicating that a more preferred type of concentrate could have the potential to increase the total intake of each cow.

\section{Milk Yield and Composition}

During periods of concentrate changes, an increase in concentrate allowance did not result in an increase in milk yield; however, we observed an increase in the protein content of the milk. The milk yield decreased during periods of decrease in concentrate allowance, but the ECM yield was unaffected because the increase in the fat content of the milk compensated for the lower milk level. The larger response in milk yield during periods of decreased concentrate allowance than during periods of increased concentrate has been found previously (M. A. Krogh, Aarhus University, Animal Science, Foulum, Denmark; personal communication), implying that the change in milk production will appear as a delayed effect when the concentrate allowance is upregulated. However, during periods of constant concentrate allowance, the cows produced more milk when they were fed the high concentrate allowance, which is comparable to most previous findings (Halachmi et al., 2005; Weisbjerg and Munksgaard, 2008; Lawrence et al., 2015). However, Bach et al. (2007) did not find an increase in milk production with a higher concentrate allowance. Concentrate type $\mathrm{O}$ increased the daily milk production by $0.9 \mathrm{~kg}$ 
compared with type $\mathrm{S}$, which is in agreement with the study of Madsen et al. (2010).

The fat and protein content in the milk did not respond in a symmetrical pattern for periods of increase and decrease in concentrate allowance, which might be related to the changes in the concentrate-to-forage ratio. In our study, the concentrate-to-forage ratio of the total ration changed when the cows increased the intake of concentrate and, thereby, decreased the intake of the PMR. Correspondingly, a decrease in the intake of concentrate increased the intake of the PMR. An increasing concentrate-to-forage ratio will increase the risk of a lowered $\mathrm{pH}$ in the rumen, which can result in changes of milk fat synthesis in the mammary glands, probably caused by adjustments in the proportions of the concentrations of VFA in the rumen (Sutton et al., 2003) or through alterations in the ruminal biohydrogenation pathways (Ventto et al., 2017). The concentrateto-forage ratio of the total ration was the highest when the cows were offered concentrate type $\mathrm{O}$ at $6 \mathrm{~kg} / \mathrm{d}$ compared with the other treatment combinations, possibly explaining why this combination of concentrate amount and type gave the lowest fat content in the milk. The protein concentration in the milk was the highest for multiparous DJ cows when the cows were offered concentrate type $\mathrm{O}$ at $6 \mathrm{~kg} / \mathrm{d}$, which might reflect an increased energy level in the total ration (Alstrup et al., 2016; Gaillard et al., 2016).

\section{Behavioral Responses}

Visits to the $\boldsymbol{A M U}$. Similar to our study, most previous studies did not find an effect of an increased concentrate allowance on daily milkings (Halachmi et al., 2005; Bach et al., 2007; Jago et al., 2007). However, Weisbjerg and Munksgaard (2008) found an increase in daily milking but only when the energy density of the PMR was low. In our study, the daily visit frequency did not change with the concentrate level during periods of a constant concentrate allowance. As the daily visit frequency during the constant concentrate allowance was the same for the 2 levels of concentrate allowance, the negative slope of visit frequency during periods of increased concentrate allowance was not expected; this possibly reflected that the cows were adjusting to the changes. The daily milkings in the current study were high compared with previous studies conducted at an AMU (Deming et al., 2013; Bach and Cabrera, 2017). The relatively high daily milking frequency and the increase in daily milkings when the cows were offered concentrate type $\mathrm{O}$ compared with type $\mathrm{S}$ indicated that the stocking density in the AMU was not too high to hinder an increase in the frequency of milkings. The effect of concentrate type $\mathrm{O}$ on the daily milkings suggests that the cows were more motivated to enter the AMU when concentrate type $\mathrm{O}$ was offered, and the palatability was probably the most important difference between the 2 concentrate types. These results are comparable to previous research findings; therefore, it seems possible to motivate the cow to enter the AMU just by adjusting the palatability of the concentrate (Madsen et al., 2010; Harper et al., 2016).

Eating Behavior. The treatments applied in our study only had a minor effect on the eating behavior during both periods with a constant concentrate allowance and during periods of increased and decreased concentrate allowance. However, the change in the PMR intake and the change in the PMR eating time correspond nicely, as the cow will spend approximately 10 min on consuming $1 \mathrm{~kg}$ of DM PMR based on our results. The decrease in the PMR intake during periods of increased concentrate allowance resulted in a combination of a shorter PMR eating time and a slower PMR eating rate. However, during periods of decreased concentrate allowance, the cows also ate at a slower rate even though the PMR intake and PMR eating time increased, which is the opposite of what is described in a previous study (Bach et al., 2007).

The stocking density at the PMR feed bins was relatively high in our study, which might have caused a high PMR eating rate. The PMR eating rate of our study was $20 \mathrm{~g}$ of $\mathrm{DM} / \mathrm{min}$ higher than the eating rate found in the study by Bach et al. (2007) in which the cows were given a high concentrate allowance; however, it was comparable to the study by Azizi et al. (2010) in which the same stocking density was provided at the feed bins. Additionally, the PMR eating rate in our study was comparable to the eating rate of cows subjected to time restraints for both eating and lying behavior (Munksgaard et al., 2005). The higher eating rate for multiparous cows during periods of increase in concentrate allowance was comparable to the results of Azizi et al. (2010) for cows fed a ration without changes in the concentrate allowance.

Lying Behavior and Steps. The lying time increased by 17 min during the periods of increased concentrate allowance and by $28 \mathrm{~min}$ during the periods of decreased concentrate allowance, even though no differences were found in the lying time between the 2 levels of concentrate amount during periods of constant concentrate allowance. This difference cannot be explained by variations in time spent eating the PMR, as the PMR eating time only changed by 7 to 8 min during the weeks of concentrate changes and the PMR eating time also increased during periods of decreased concentrate allowance. Therefore, these findings suggest that 
the cows prioritized lying time more when the amount of concentrate was regulated. However, the cows spent less time lying when provided with concentrate type O. These results suggest that the lying time may be affected negatively when changing the concentrate type but not when the concentrate amount is changed, at least with a relatively high-energy concentration in the PMR. As the lying time only decreased when a new concentrate type was offered, and this change did not affect the PMR eating time or the PMR eating rate, this finding implies that the cows were not limited in time for lying. The DH cows were lying less when concentrate type $\mathrm{O}$ was offered compared with type $\mathrm{S}$, but this decrease was not caused by an increase in the PMR eating time. Therefore, it is possible that the decrease in lying time reflects an increased waiting time at the AMU. Additionally, during periods of decrease in concentrate allowance, the daily number of steps decreased, possibly reflecting the cows spending more time lying. The lying time duration was comparable to findings in other studies conducted at an AMU on Holstein cows (Devries et al., 2011; Deming et al., 2013). One previous study performed in the same barn also found that the mean daily lying time was shorter for DJ cows than for DH cows (Campler et al., 2014).

In summary, some of the responses that differed with concentrate level during periods of constant concentrate allowance could not be identified during periods of increased or decreased concentrate allowance, and other responses changed during the periods of concentrate changes without showing any difference between the 2 concentrate levels during periods with a constant concentrate allowance. Hence, these results indicate that it may be difficult to regulate the individual concentrate allowance based on the short-term responses of the cow.

\section{CONCLUSIONS}

The cows visited the AMU more often when concentrate type $\mathrm{O}$ was offered, but not with an increased concentrate allowance. Changes in the concentrate allowance affected the visit frequency to the AMU negatively during periods of increased concentrate allowance and the milk yield negatively during periods of decreased concentrate allowance. The cows did not seem to be limited in time for eating and lying, even though they had a relatively high PMR eating rate. The PMR eating rate and lying time did not differ between the 2 levels of constant concentrate allowance, but they showed linear changes during periods of concentrate changes, indicating that the cows were trying to adjust to the changing concentrate allowance.

\section{ACKNOWLEDGMENTS}

This work was funded by Mælkeafgiftsfonden (Milk Levy Fund, Aarhus, Denmark). The authors thank the staff at the Danish Cattle Research Center (Foulum, Denmark) for their highly committed engagement during the experiment. Connie H. Middelhede and Martin Bjerring (Aarhus University, Animal Science, Foulum, Denmark) are acknowledged for their efforts on data processing.

\section{REFERENCES}

Alstrup, L., K. Soegaard, and M. R. Weisbjerg. 2016. Effects of maturity and harvest season of grass-clover silage and of forage-toconcentrate ratio on milk production of dairy cows. J. Dairy Sci. 99:328-340.

AOAC International. 2000. Official Methods of Analysis. 15th ed. AOAC International, Washington, DC.

Atwood, S. B., F. D. Provenza, R. D. Wiedmeier, and R. E. Banner. 2001. Influence of free-choice vs. mixed-ration diets on food intake and performance of fattening calves. J. Anim. Sci. 79:3034-3040.

Azizi, O., L. Hasselmann, and O. Kaufmann. 2010. Variations in feeding behaviour of high-yielding dairy cows in relation to parity during early to peak lactation. Archiv Fur Tierzucht-Archives of Animal Breeding 53:130-140.

Bach, A., and V. Cabrera. 2017. Robotic milking: Feeding strategies and economic returns. J. Dairy Sci. 100:7720-7728.

Bach, A., C. Iglesias, S. Calsamiglia, and M. Devant. 2007. Effect of amount of concentrate offered in automatic milking systems on milking frequency, feeding behavior, and milk production of dairy cattle consuming high amounts of corn silage. J. Dairy Sci. 90:5049-5055.

Bossen, D., and M. R. Weisbjerg. 2009. Allocation of feed based on individual dairy cow live weight changes. Effect on milk production. Livest. Sci. 126:273-285.

Bossen, D., M. R. Weisbjerg, L. Munksgaard, and S. Højsgaard. 2009 Allocation of feed based on individual dairy cow live weight changes. Feed intake and live weight changes during lactation. Livest. Sci. 126:252-272.

Campler, M., M. B. Jensen, and L. Munksgaard. 2014. The effect of housing on dairy cattle behavior during the transition period. The effect of housing on behavior during the dry period in Holstein and Jersey cows. PhD thesis. Science and Technology, Aarhus University, Aarhus, Denmark.

Deming, J. A., R. Bergeron, K. E. Leslie, and T. J. DeVries. 2013 Associations of cow-level factors, frequency of feed delivery, and standing and lying behaviour of dairy cows milked in an automatic system. Can. J. Anim. Sci. 93:427-433.

Devries, T. J., J. A. Deming, J. Rodenburg, G. Seguin, K. E. Leslie, and H. W. Barkema. 2011. Association of standing and lying behavior patterns and incidence of intramammary infection in dairy cows milked with an automatic milking system. J. Dairy Sci. 94:3845-3855.

Dewhurst, R. J., J. M. Moorby, M. S. Dhanoa, and W. J. Fisher. 2002. Effects of level of concentrate feeding during the second gestation of Holstein-Friesian dairy cows. 1. Feed intake and milk production. J. Dairy Sci. 85:169-177.

European Community. 2012. First commission directive of 15 June 1971 establishing Community methods of analysis for the official control of feeding-stuffs $(71 / 250 / \mathrm{EEC})$.

Ferguson, J. D., D. T. Galligan, and N. Thomsen. 1994. Principal descriptors of body condition score in Holstein cows. J. Dairy Sci. 77:2695-2703.

Gaillard, C., N. C. Friggens, M. Taghipoor, M. R. Weisbjerg, J. O Lehmann, and J. Sehested. 2016. Effects of an individual weight- 
adjusted feeding strategy in early lactation on milk production of Holstein cows during extended lactation. J. Dairy Sci. 99:22212236 .

Halachmi, I., S. Ofir, and J. Miron. 2005. Comparing 2 concentrate allowances in an automatic milking system. Anim. Sci. 80:339-343.

Hansen, B. 1989. Determination of nitrogen as elementary-N, an alternative to Kjeldahl. Acta Agric. Scand. 39:113-118.

Harper, M. T., J. Oh, F. Giallongo, J. C. Lopes, H. L. Wk, J. Faugeron, and A. N. Hristov. 2016. Short communication: Preference for flavored concentrate premixes by dairy cows. J. Dairy Sci. 99:6585-6589.

Henriksen, J. C. S., and L. Munksgaard. 2016. Technical note: Validation of a device for automatically measuring of lying behaviour in dairy cows. Book of Abstracts of the 67th Annual Meeting of the European Federation of Animal Science. No. 22:484. Wageningen Academic, Wageningen, the Netherlands.

Jago, J. G., K. L. Davis, P. J. Copeman, I. Ohnstad, and M. M. Woolford. 2007. Supplementary feeding at milking and minimum milking interval effects on cow traffic and milking performance in a pasture-based automatic milking system. J. Dairy Res. 74:492-499.

Jensen, L. M., B. Markussen, N. I. Nielsen, E. Nadeau, M. R. Weisbjerg, and P. Norgaard. 2016. Description and evaluation of a net energy intake model as a function of dietary chewing index. J. Dairy Sci. 99:8699-8715.

Knudsen, K. E. B., P. Åman, and B. O. Eggum. 1987. Nutritive value of Danish-grown barley varieties, I, carbohydrates and other major constituents. J. Cereal Sci. 6:173-186.

Kristensen, T., O. Aaes, and M. R. Weisbjerg. 2015. Production and environmental impact of dairy cattle production in Denmark 1900-2010. Livest. Sci. 178:306-312.

Larsen, M. K., M. R. Weisbjerg, C. B. Kristensen, and G. Mortensen. 2012. Short communication: Within-d variation in fatty acid composition of milk from cows in an automatic milking system. J. Dairy Sci. 95:5608-5611.

Lawrence, D. C., M. O'Donovan, T. M. Boland, E. Lewis, and E. Kennedy. 2015. The effect of concentrate feeding amount and feeding strategy on milk production, dry matter intake, and energy partitioning of autumn-calving Holstein-Friesian cows. J. Dairy Sci. 98:338-348.

Littell, R. C., G. A. Milliken, W. W. Stroup, R. D. Wolfinger, and O. Schabenberger. 2006. SAS for Mixed Models. 2. ed. SAS Institute Inc., Cary NC.

Løvendahl, P., and M. A. Bjerring. 2006. Detection of carryover in automated milk sampling equipment. J. Dairy Sci. 89:3645-3652.

Madsen, J., M. R. Weisbjerg, and T. Hvelplund. 2010. Concentrate composition for automatic milking systems - Effect on milking frequency. Livest. Sci. 127:45-50.

Meagher, R. K., D. M. Weary, and M. A. G. von Keyserlingk. 2017. Some like it varied: Individual differences in preference for feed variety in dairy heifers. Appl. Anim. Behav. Sci. 195:8-14.

Mertens, D. R., M. Allen, J. Carmany, J. Clegg, A. Davidowicz, M. Drouches, K. Frank, D. Gambin, M. Garkie, B. Gildemeister, D.
Jeffress, C. S. Jeon, D. Jones, D. Kaplan, G. N. Kim, S. Kobata, D. Main, X. Moua, B. Paul, J. Robertson, D. Taysom, N. Thiex, J. Williams, and M. Wolf. 2002. Gravimetric determination of amylase-treated neutral detergent fiber in feeds with refluxing in beakers or crucibles: Collaborative study. J. AOAC Int. 85:1217-1240. Munksgaard, L., M. B. Jensen, L. J. Pedersen, S. W. Hansen, and L. Matthews. 2005. Quantifying behavioural priorities-effects of time constraints on behaviour of dairy cows, Bos taurus. Appl. Anim. Behav. Sci. 92:3-14.

Østergaard, V., C. C. Krohn, and I. Thysen. 1987. Feeding principles and optimum feeding of the high yielding dairy cow. Pages 126-139 in Cattle Production Research. Danish Status and Perspectives. Statens Husdyrbrugforsøg, Landhusholdningsselskabets Forlag, Copenhagen, Denmark.

Primdal, L., M. Johansen, and M. R. Weisbjerg. 2014. Do cows have preferences for different concentrate feeds? Proc. Aust. Soc. Anim. Prod. 30:363.

Schingoethe, D. J. 2017. A 100-year review: Total mixed ration feeding of dairy cows. J. Dairy Sci. 100:10143-10150.

Sjaunja, L. O., L. Baevre, L. Junkkarinen, J. Pedersen, and J. Setala. 1991. A nordic proposal for an energy corrected milk ECM formula. Pages 156-192 in Gaillon, P. and Y. Chabert. European Association for Animal Production Publication, No. 50. Performance Recording of Animals: State of the Art, 1990; 27th Biennial Session of the International Committee for Animal Recording, Paris, France, July 2-6, 1990. Centre for Agricultural Publishing and Documentation. Wageningen Academic, Wageningen, the Netherlands.

Sutton, J. D., M. S. Dhanoa, S. V. Morant, J. France, D. J. Napper, and E. Schuller. 2003. Rates of production of acetate, propionate, and butyrate in the rumen of lactating dairy cows given normal and low-roughage diets. J. Dairy Sci. 86:3620-3633.

Thomsen, P. T., L. Munksgaard, and F. A. Togersen. 2008. Evaluation of a lameness scoring system for dairy cows. J. Dairy Sci. 91:119-126.

Ventto, L., H. Leskinen, P. Kairenius, T. Stefanski, A. R. Bayat, J. Vilkki, and K. J. Shingfield. 2017. Diet-induced milk fat depression is associated with alterations in ruminal biohydrogenation pathways and formation of novel fatty acid intermediates in lactating cows. Br. J. Nutr. 117:364-376.

Volden, H. 2011. Norfor-The Nordic feed evaluation system. EAAP Publications. No. 130. Wageningen Acedemic Publishers, Wageningen, the Netherlands.

Weisbjerg, M. R., and T. Hvelplund. 1993. Bestemmelse af nettoenergiindhold (FEK) i råvarer og kraftfoderblandinger. Page $39 \mathrm{pp}$ in Forskningsrapport nr. 3. Statens Husdyrbrugsforsøg, Copenhagen, Denmark.

Weisbjerg, M. R., and L. Munksgaard. 2008. Kraftfoderstrategier i et AMS system. Malkekoens fodring, Fodringstrategier og aktuel forskning, Intern rapport. Pages 21-30 in DJF Husdyrbrug. Vol. April. M. R. Weisbjerg, ed. Det jordbrugsvidenskabelige institut, Aarhus, Denmark. 